\title{
Çölyak hastalarında depresyon ve cinsel disfonksiyon sıklığı, hormonal dengenin cinsel disfonksiyonun üzerine etkilerinin belirlenmesi
}

\author{
Frequency of depression and sexual dysfunction in celiac patients: Identification of the effects of \\ hormonal balance on sexual dysfunction
}

\author{
Selen ŞIPAL'1 , Mesut SEZIKLi², Gökhan DINDAR² \\ ${ }^{1}$ Van Bölge Eğitim ve Araştırma Hastanesi, Iç Hastalıkları Kliniği, Van \\ ${ }^{2}$ Kocaeli Derince Eğitim ve Araştırma Hastanesi, Gastroenteroloji Kliniği, Kocaeli
}

\begin{abstract}
Giriş ve Amaç: Çölyak hastalığı; genetik olarak yatkın bireylerde gluten içeren buğday, arpa, çavdar gibi gıdaların alınmasılla tetiklenen immün aracılı bir enteropati olup hastalarda intestinal ve ekstraintestinal problemlere yol açar. Bu çalışmada, çölyak hastalarında hem sıkı glutensiz diyetin hem de glutenle tetiklenen kronik inflamasyonun erişkin yaşlarda getirebileceği seksüel ve psikolojik disfonksiyonların saptanması amaçlanmıştır. Gereç ve Yöntem: Çalışmaya en az 1 yıllık çölyak hastalığı tanııı olup takipte olan 79 hasta ile (53 kadın 26 erkek) yaş ve cins uyumlu 48 sağlıklı kontrol grubu (29 kadın 19 erkek) dahil edildi. Tüm katılımcılardan Beck Depresyon Anketini ve uygun olan katılımcılardan Kadın Seksüel Fonksiyon Indeks ve Ereksiyon Işlevi Uluslararası Değerlendirme Formunu doldurmaları istendi. Cinsel işlev formunu dolduracak olan katılımcilardan total testesteron, dehidroepiandrosteron, folikül stimüle edici hormon, lüteinize edici hormon, tiroid stimulan hormon, estradiol ve prolaktin ölçümleri için kan örnekleri alındı. Bulgular: Beck Depresyon Anketini doğru ve eksiksiz dolduran hasta grubundaki 70 katılımanın \%33'ünde $(n=23)$ kontrol grubundaki ise 38 katılımanın $11^{\prime}$ inde (\%30) depresif semptomlar tespit edilmiş olup hasta ve kontrol grubundaki depresyon oranları benzerdi. Kontrol grubunun üre, ferritin, hemoglobin ve total kolesterol düzeyleri hasta grubuna göre daha yüksekken (sırasıly $p=0,019 p=0,03 p=0,010$ $p=0,02)$ bütün katılımcıların hemoglobin düzeyleri ile Beck Depresyon Skorları arasındaki negatif korelasyon dikkat çekti $(p=0,03)$. Katılımcılardan cinsel aktif olan hasta grubundaki 30 kadın ile kontrol grubundaki 12 kadın Kadın Seksüel Fonksiyon Indeksi anketine göre değerlendirildiğinde cinsel disfonksiyon açısından benzer bulundu (sırasıyla \%30, $\% 42, p>0,05)$. Kadınlardaki cinsel disfonksiyon ile hastalık aktivitesi, hormonal denge ve depresyon arasında bir ilişki bulunamadı. Yine hasta $(n=15)$ ve kontrol $(n=7)$ grubundaki cinsel aktif erkek katilımcların Ereksiyon Işlevi Uluslararası Değerlendirme Formu anketine göre erektil disfonksiyon açısından aralarında istatiksel fark bulunamazken (sırasıyla $\% 53, \% 28,6 p>0,05)$ hasta grubundaki total testesteron düzeyi sağlıklı kontrol grubuna göre daha yüksek $(p=0,030)$ estradiol düzeyi ise daha düşük saptandı $(p=0,039)$. Yine hastalık aktivitesi, hormonal denge ve depresyon ile erktil disfonksiyon arasında ilişki bulunamadı.Sonuç: Çölyak hastaları ile kontrol grubundaki depresyon oranları benzer olmakla birlikte hemoglobin düzeylerindeki düşüklüğün hastalıktan bağımsız olarak depresyon skorlarını etkilediği görülmektedir. Cinsel aktif erkek ve kadınlardaki cinsel disfonksiyon oranları her iki grupta da benzer iken çölyaklı erkeklerdeki total testesteron düzeylerindeki yüksekliğin androjen direnci ile ilgisi olabileceği düşünüldü. Sonuç olarak çölyakı kadın ve erkeklerde cinsel disfonksiyon ve hormonal denge ile ilgili daha çok katıımcı ile yapılacak büyük çalışmalara ihtiyaç vardır.
\end{abstract}

Anahtar kelimeler: Çölyak hastalığı, depresyon, cinsel disfonksiyon

Iletişim: Mesut SEZIKLL

Kocaeli Derince Eğitim ve Araştırma Hastanesi, Gastroenteroloji Kliniği, Kocaeli Tel: +902623178000

E-mail: drsezikli@hotmail.com
Background and Aims: Celiac disease is an immune enteropathy triggered by the ingestion of gluten-containing foods such as wheat, barley, and rye in genetically predisposed individuals and the cause of intestinal and extraintestinal symptoms. In this study, we aimed to detect sexual and psychological dysfunction, which can be brought on by both a strict gluten-free diet and gluten-triggered chronic inflammation in adulthood in celiac patients. Material and Methods: In this study, 79 patients (53 female) who were diagnosed with celiac disease and followed for at least 1 year and 48 age- and sex-matched healthy controls (29 female) were included. All the participants were asked to complete the Beck Depression Questionnaire and eligible participants were asked to fill out Female Sexual Function Index and International Index of Erectile Function forms. Blood samples were collected for measurement of total testosterone, dehydroepiandrosterone sulfate, follicle-stimulating hormone, luteinizing hormone, thyroid stimulating hormone, estradiol, and prolactin. Results: Depression was detected in $33 \%(n=23)$ of 70 participants in the patient group and in 11 (30\%) of 38 participants in the healthy control group who filled out the Beck Depression Questionnaire completely and accurately, and depression rates were similar in both groups. While the control group's urea, ferritin, hemoglobin, and total cholesterol levels were higher than those in the patient group ( $p=0.019, p=0.03, p=0.010, p=0.02$, respectively), a strong negative correlation between all participants' hemoglobin levels and Beck Depression scores $(p=0.03)$ was found. When sexually active female participants were evaluated (30 females in the patient group and 12 females in the control group) according to the Female Sexual Function Index questionnaire, sexual dysfunction rates were similar in the two groups $(30 \%, 42 \%, p>0.05$, respectively). There was no relationship between the women's sexual dysfunction and disease activity, hormonal balance, or depression. Similarly, when sexually active male participants were evaluated (15 males in the patient group and 7 males in the control group) according to the Female Sexual Function Index questionnaire, there was no statistically significant difference between the two groups in the rate of erectile dysfunction $(53 \%, 28.6 \%, p>0.05$, respectively), despite the higher total testosterone levels $(p=0.030)$ and lower estradiol levels $(p=0.039)$ in the patient group. There was also no relationship found between erectile dysfunction and disease activity, hormonal balance, or depression. Conclusion: Although depression rates were similar between celiac patients and controls, it was shown that low hemoglobin levels affected depression scores independently of the disease. Although sexually active women and men had similar sexual dysfunction rates in both groups, higher total testosterone levels in male participants with celiac disease might be evidence of androgen resistance. As a result, larger studies with more participants are needed in women and men with celiac disease, examining sexual dysfunction and hormonal balance.

Key words: Celiac disease, depression, sexual dysfunction 


\section{GiRiş ve AMAÇ}

Çölyak hastalığı (ÇH) glutene karşı gelişmiş immün aracılı bir reaksiyondur. HLADQ-2 ve/veya HLADQ-8 haplotipleri taşıyan genetik olarak yatkın kişilerde ince bağırsağın inflamatuvar hasarına yol açan uygun olmayan bir T hücre aracılı immün yanıt ile karakterize edilen bir hastalıktır (1). Dünya çapındaki prevalansının \%0,6 ile \%1 olduğu bilinen bu hastalığın günümüzde bilinen tek tedavi yöntemi sıkı glutensiz diyet yapmaktır $(2,3)$. Çölyak hastalığı Down ve Turner sendromu gibi genetik bozukluklara, otoimmün hastalıklara, kadınlarda ve erkeklerde infertilite problemlerine eşlik edebilir (4).

Kişisel ve toplumsal maliyetleri göz önünde bulundurulduğunda ciddi bir halk sağlığı sorunu olan depresyon, tedavi edilmemiş çölyak hastalarında sık görülen psikiyatrik semptomların başında gelir (5-8). Çölyak hastalarında hem gluten alımılla ilişkili intestinal ve ekstraintestinal bulguların, hem de sıkı glutensiz diyetin uygulanmasındaki zorluğun ve diyeti uygularken hastalarda gelişebilen nutrisyonel yetersizliğin normal popülasyona göre depresyon sıklığını artııran faktörler olabileceği, yine çölyak hastalığına eşlik eden otoimmün tiroiditin hastalarda depresyon sıklığını arttırdığı yapılan çalışmalarda gösterilmiştir (9-12).

Seksüel disfonksiyon kronik hastalıklarda yoğun strese bağlı sık görülen bir semptom olmasına karşın çölyak hastalarında bununla ilgili çok az literatür bulunmaktadır. Çölyak hastalı̆ı̆ olan kadınlarda geç menarş, erken menopoz, sekonder amenore gibi hipogonadal bulguların yanı sıra tekrarlayan düşükler, infertilite, erken doğum ve düşük doğum ağırlığı gibi fertilite sorunları da seksüel disfonksiyonu tetikleyen nedenler arasında olabilir $(1,4)$. Erkeklerde görülen anormal sperm motilitesi ve morfolojisinin yanı sıra, artmış androjen direnci [yüksek serum testesteron ve lüteinize edici hormon (LH) düzeyleri] infertiliteden sorumlu tutulurken, düşük testesteron düzeyleri ile birlikte görülen libido azalması seksüel disfonksiyonla ilişkilendirilmiştir $(13,14)$.

Bu çalışmada, tanısı genellikle çocukluk çağında konulan çölyak hastalığında hem sıkı glutensiz diyetin hem de glutenle tetiklenen kronik inflamasyonun erişkin yaşlarda getirebileceği seksüel ve psikolojik disfonksiyonların saptanması amaçlanmıştır.

\section{GEREÇ ve YÖNTEM}

Çalışmaya 18 yaş üzerindeki, çölyak hastalığı tanısı nedeniyle en az 1 yıllık rutin takipte olan, araştırmaya katılmayı kabul eden, soruları anlayabilecek ve düşüncelerini aktarabilecek yeterliliği olan 26'sı erkek 53'ü kadın olan toplam 79 hasta alındı. Yaş ve cinsiyet uyumlu, ciddi siste- mik hastalığı bulunmayan, menstrual siklusları düzenli ve kıllanma artışı yakınması olmayan, rutin kontrol amaçlı iç Hastalıkları polikliniğe başvuran ve araştırmaya katılmayı kabul eden 19'u erkek 29'u kadın toplam 48 kişilik sağlıkIı kontrol grubu seçildi. Hasta ve kontrol grubundaki tüm katılımcılardan depresyon semptomlarını değerlendirmek için 20 soruluk Beck Depresyon Anketini (BDA) ve cinsel olarak aktif olan, partneriyle düzenli ilişkisi olan ve soruları anlayıp cevaplayacak yeteneği olan katılımcılardan cinsel disfonksiyonu değerlendirmek için Kadın Seksüel Fonksiyon Indeksi (FSFI) ve Ereksiyon Isşlevi Uluslararası Değerlendirme Formu (IIEF) anketlerini doldurmaları istendi. Tüm anketlerin Türk popülasyonunda uygunluğu yapılmış olup tek bir araştırmacı tarafından değerlendirilmiştir. Hasta ve sağılıkı kontrol grubundaki kadınlardan erken foliküler fazda, erkeklerden herhangi bir zamanda aç olarak kan örneği alındı. Bu kanlardan, hemogram, dehidroepiandrosteron sülfat (DHEA-S), total testesteron, folikül stimüle edici hormon (FSH), lüteinize edici hormon (LH), tiroid stimüle edici hormon (TSH), doku transglutaminaz immünglobulin $\mathrm{A}$ (tTG IgA) çalışıldı.

İstatistiksel değerlendirme, IBM SPSS 20.0 (SPSS Inc., Chicago, IL, USA) paket programı ile yapıldı. Normal dağılıma uygunluk testi Kolmogorov-Smirnov Testi ile değerlendirildi. Normal dağılım gösteren nümerik değişkenler ortalama +/- standart sapma, normal dağılım göstermeyen nümerik değişkenler medyan (25. persantil - 75. persantil), kategorik değişkenler ise frekans (yüzde) olarak verildi. Gruplar arasındaki farklıık normal dağılıma sahip olan nümerik değişkenler için student-t testi ile, normal dağııma sahip olmayan nümerik değişkenler için ise Mann Whitney U Testi ile belirlendi. Kategorik değişkenler arasındaki ilişkileri saptamak için Ki-kare analizi kullanıldı. Nümerik değişkenler arasındaki ilişkiler ise normallik varsayımı sağlanmadığından Spearman korelasyon analizi ile belirlendi. $p<0.05$ istatistiksel olarak önemlilik için yeterli kabul edildi.

\section{BULGULAR}

Çalışmaya alınan 79 çölyak hastasının 53'ü (\%67) kadın, 26'sı (\%33) erkekti. Hasta grubunun yaş ortalaması $40,63 \pm 13,7$ olup; kadınların yaş ortalaması $(38,4 \pm 12,08)$ erkeklere göre $(45 \pm 16,02)$ daha küçüktü $(p=0,047)$. Hastalar hastalık aktivitesi açısından değerlendirildiğinde 31 (\%40) hastanın tTG-IgA düzeyi pozitif saptandı ve bu hastalar tedavisiz kalan veya kontrol altına alınamayan çölyak hastası olarak kabul edildi.

Kırk sekiz sağlıklı bireyden oluşan kontrol grubunda ise hastaların 29'u (\%60) kadın, 19'u (\%40) erkekti. Kontrol grubunun yaş ortalaması $39,89 \pm 13,90$ olup kadınlar ile

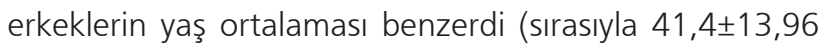


ve $37,5 \pm 13,86 p>0,05)$. Hasta ve kontrol grubu yaş, cinsiyet bakımından değerlendirildiğinde yaş ve cinsiyet dağıll$m ı$ her iki grupta benzerdi $(p>0,05)$.

Çalışmamızdaki hastalar en az 1 yıllık çölyak hastası olup bu hastalarda hastalık aktivitesi doku transglutaminaz IgA ve IgG düzeyleri ile belirlendi. tTG-IgA veya IgG düzeyleri negatif olan hastalar yeterli diyet uyumu olan hastalar olarak değerlendirildi. Bu verilere göre Beck Depresyon Anketini dolduran 70 çölyak hastasından 40'ında (\%57) diyet uyumu yeterliyken, 30'unda (\%43) hastalık aktifti. Diyet uyumu yeterli olan 40 hastanın 14'ünde (\%35) ve hastalığı aktif olan 30 hastanın 9'unda (\%30) depresif semptomlar bulundu. Sonuç olarak bizim çalışmamızda da diyet uyumu yeterli olan hastalar ile aktif hastalığı olan hastaların depresyon semptoları açısından benzer olduğu görüldü $(p>0,05)$.

Beck Depresyon Anketini (BDA) doğru ve eksiksiz dolduran hasta grubundaki 70 katılımcının \%33'ünde $(n=23)$, kontrol grubunda ise 38 katılımcının 11'inde (\%30) BDA skorlamasında 17 ve üzerinde puan tespit edilmiş olup, bu katılımcilar depresyon semptomları bulunduran katılımcılar olarak değerlendirildi. Tüm hasta grubu depresyon açısından sağlıkı kontrol grubu ile kıyaslandığında, Beck Depresyon Anketini dolduran 108 hastadan 34'ü $(\% 31,5)$ depresyondaydı. Bu hastaların \%10'u ( $n=11)$ sağlıklı gruptayken \%21'i $(n=23)$ hasta grubundaydı. Bu fark istatiksel olarak anlamlı değildi ( $p>0,05)$, ( Grafik 1).

Hasta ve kontrol grubu ayrı ayrı değerlendirildiğinde kadın ve erkekler arasında depresyon açııından fark yoktu

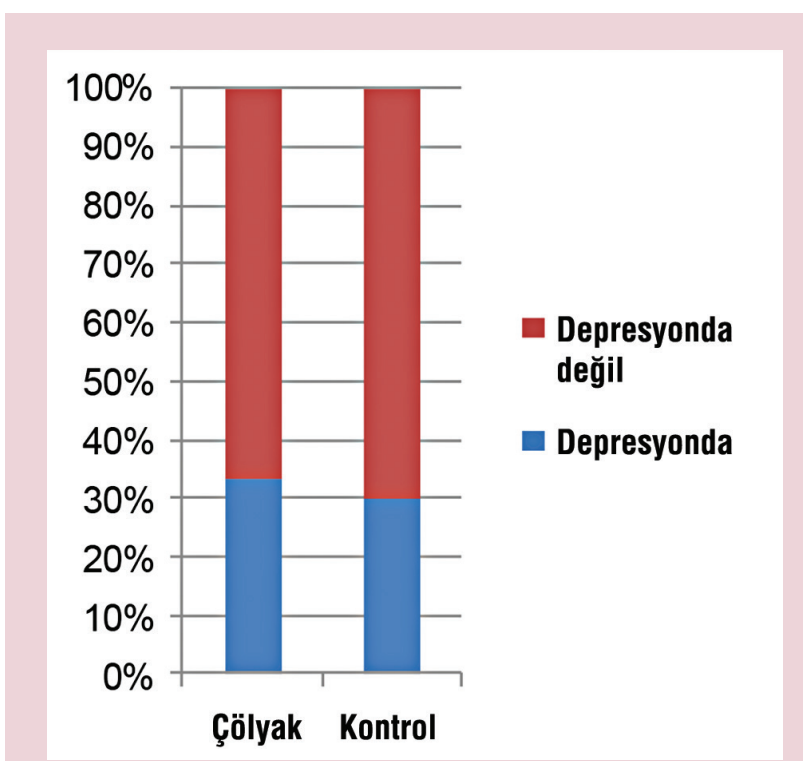

Grafik 1. Hasta ve kontrol grubunda depresyon görülme oranlarının dağııımı (srasiyla $p=0,83$ ve $p=0,26$ ). Tüm hasta grubunda depresyon üzerine; yaş, beden kitle indeksi (BMI), hastalık aktivitesi, otoimmün hastalık veya diğer ek hastalık durumunun ve sigara kullanımının etkisi bulunamadı $(p>0,05)$.

Her iki grupta hemoglobin düzeyi $12 \mathrm{~g} / \mathrm{dl}$ 'nin altında olanlar anemik olarak değerlendirildiğinde katılımcılardan 61 'i (\%48) anemikti. Bu katılımclardan \%70,5'i $(n=43)$ hasta grubundayken, \% 29,5'i ( $n=18)$ kontrol grubundaydı $(p>0,05)$. Kontrol grubunda anemisi olan hastaların $\% 94 ' u ̈(n=17)$, hasta grubunda ise \%86'sı ( $n=37)$ kadındı $(p=0,00)$. Anemik olan hastaların $\% 74$ 'ünde $(n=45)$ demir eksikliği anemisi bulunurken, bunların \%64'ü $(n=29)$ hasta grubunda, \%36'sı ( $n=19)$ kontrol grubundaydı $(p>0,05)$. Subgrup analizinde ise anemisi olanlarda depresyon semptomları görülme oranları karşllaştıııldığında istatiksel bir fark saptanmazken $(p>0,05)$, hemoglobin düzeyleri ile Beck Depresyon Skorları arasında negatif korelasyon bulundu $(p=0,030)$. Hastalar cinsiyetlerine göre karşılaştırılığında hasta grubundaki 53 kadın hastadan 30 'u cinsel olarak aktifti. Bu 30 hastanın \%30'unda $(n=9)$ FSFI skoruna göre 26,5 ve altında puan tespit edilmiş olup bu hastalar cinsel disfonksiyonu olan hastalar olarak değerlendirildi. Bu hastalar hormon düzeylerine göre karşılaştırıldı̆ında cinsel disfonksiyonu olanlarda prolaktin düzeyi olmayanlara göre yüksek iken, estradiol düzeyi cinsel disfonksiyonu olanlarda daha düşük bulundu. Ancak bu farkın istatiksel olarak anlamı yoktu (sırasıyla $p=0,304$ ve $p=0,894)$. DHEA-S, total testesteron, $F S H, L H, T S H$ düzeyleri her iki hasta grubunda benzerdi $(p>0,05)$. Hasta grubunda cinsel disfonksiyon üzerine hastalık aktivitesi ve depresyonun etkisi bulunmadı.

Sağlıklı kontrol grubundaki 29 kadından cinsel aktif olanlar ve FSFI anketini doğru ve eksiksiz dolduran 12 kadın değerlendirilmeye alındığında \%42'sinde $(n=5)$ cinsel disfonksiyon tespit edildi. Kontrol grubu kendi içinde hormonal olarak değerlendirildiğinde cinsel disfonksiyonu olanlarda total testesteron düzeyi daha yüksek bulunmasına rağmen bu fark istatistiksel olarak anlamlı değildi $(p=0,215)$. DHEA-S, estradiol, prolaktin, FSH/LH oranı, TSH düzeyleri her iki kontrol grubunda benzerdi $(p>0,05)$. Depresyonun cinsel disfonksiyon üzerine etkisine bakıldığında anlamlı bir fark bulunamadı.

Hasta ve sağlıklı gruptaki cinsel aktif kadınlar karşılaştırıdığında FSFI total ve alt grup skorları kontrol grubunda daha yüksek olmakla birlikte istatiksel olarak anlamlı değildi $(p>0,05)$. Her iki gruptaki kadınlarda cinsel disfonksiyon görülme oranları birbirine benzerdi $(p>0,05)$. Her iki grup hormon düzeylerine göre karşılaştırıldığında ise kontrol grubunda DHEA-S ve estradiol düzeyleri hasta grubuna göre yüksek bulunmasına rağmen istatiksel ola- 
rak anlamı yoktu $(p>0,05)$. Hasta grubundaki cinsel aktif kadınların TSH düzeyleri kontrol grubuna göre anlamlı olarak yüksek bulundu $(p=0,01)$. Her iki grupta $\mathrm{FSH} / \mathrm{LH}$ oranlarının ortalama değerleri 1 'in üzerindeydi, bu oran kontrol grubunda hasta grubuna oranla daha yüksek olmakla beraber anlamlı değildi $(p=0,205)$. Depresyon ve sigaranın cinsel disfonksiyon üzerine anlamlı bir etkisi yoktu $(p>0,05)$.

Hasta grubundaki 26 erkekten cinsel aktif olan 15 hasta IIEF anketine göre değerlendirildiğinde hastaların $\% 53,3^{\prime}$ ünde $(n=8)$ erektil disfonsiyon saptandı. Cinsel aktif erkeklerde hormonların erektil disfonksiyon üzerine etkisi araştırıldığında, her iki hasta grubunda da TSH, FSH/ LH, DHEA-S ve estradiol düzeyleri benzer bulunurken $(p>0,05)$ prolaktin düzeyleri erektil disfonksiyonu olanlarda belirgin olarak daha düşük saptandı ve bu fark istatiksel olarak anlamlı idi $(p=0,039)$. Total testesteron düzeyi ise erektil disfonksiyonu olanlarda daha düşük bulunmasına rağmen istatiksel olarak benzerdi. Yine hastalarda testesteron direnci açısından FSH/LH oranları değerlendirildiğinde, FSH/LH oranı 1 'in altında olan 7 hastadan sadece $3^{\prime}$ ünde $(\% 43)$ erektil disfonksiyon vardı. $(p=0,619)$ Bu hastalarda depresyon ve hastalık aktivitesinin erektil disfonksiyon üzerine etkisi bulunamadı.

Kontrol grubundaki 19 erkekten cinsel aktif olan ve IIEF anketini doğru ve eksiksiz dolduran 7 hastanın \%28,6'sında $(n=2)$ erektil disfonksiyon vardı. Her iki hasta ve kont- rol grubundaki cinsel aktif erkeklerin IIEF skorları birbirine benzerken Beck skorlarına bakıldığında hasta grubunda belirgin olarak yüksek bulunmasına karşın bu fark istatiksel olarak anlamlı değildi ( $p>0,05)$, (Tablo 1).

Hasta ve kontrol grubundaki cinsel aktif erkek hastalar hormonal açıdan değerlendirildiğinde hasta grubunda total testesteron düzeyi sağlıkı kontrol grubuna göre daha yüksek bulunurken $(p=0,030)$, estradiol düzeyi daha düşük saptandı $(p=0,039)$. DHEA-S, prolaktin, estradi$\mathrm{ol}, \mathrm{FSH} / \mathrm{LH}$ ve TSH düzeyleri ise her iki grupta benzerdi ( $p>0,05)$, (Tablo 2). Her iki grup testesteron direnci açısından değerlendirildiğinde toplam 22 cinsel aktif erkekten 9 'unda (\%41) FSH/LH oranı <1 iken bunların 7'si $(\% 77,8)$ hasta grubundaydı $(p=0,648)$.

\section{TARTIŞMA}

Çalışmamızda çölyak hastaları ile kontrol grubu arasında depresif semptom görülme sıklığı benzer bulundu ve hastalık aktivitesi, cinsiyet, otoimmün hastalıkların depresyon semptomları ile ilişkisi saptanmazken hemoglobin düzeyleri ile Beck depresyon skorları arasında negatif korelasyon tespit edildi. Çölyaklı erkeklerde erektil disfonksiyon oranları kontrol grubuna göre yüksek olmakla birlikte, istatiksel olarak anlamlı değildi. Bir başka bulgu ise çölyaklı cinsel aktif erkeklerin total testesteron düzeylerinin kontrol grubundaki erkeklere göre yüksek olması idi.

Tablo 1. Hasta ve kontrol grubundaki cinsel aktif erkeklerin IIEF ve Beck skorları

\begin{tabular}{|l|c|c|c|}
\hline & Hasta grubu (n=15), mean $\mathbf{S D}$ & Kontrol grubu (n=7), mean \pm SD & P değeri \\
\hline Erektil fonksiyon & $23,7 \pm 6,54$ & $26,0 \pm 6,19$ & 0,490 \\
\hline Orgazmik işlev & $8,53 \pm 2,23$ & $8,28 \pm 3,68$ & 0,783 \\
\hline Cinsel istek & $7,66 \pm 1,75$ & $7,71 \pm 1,70$ & 0,891 \\
\hline Cinsel memnuniyet & $10,33 \pm 2,76$ & $12,42 \pm 1,27$ & 0,056 \\
\hline Genel memnuniyet & $\mathbf{7 , 4 6 \pm 2 , 4 1}$ & $\mathbf{8 , 8 5} \pm \mathbf{0 , 8 9}$ & $\mathbf{0 , 2 3 7}$ \\
\hline Beck skoru & $\mathbf{1 2 , 6 6 \pm 3 , 0 3}$ & $\mathbf{3 , 4 2} \pm \mathbf{1 , 4 4}$ & $\mathbf{0 , 1 0 6}$ \\
\hline
\end{tabular}

\begin{tabular}{|c|c|c|c|}
\hline & Hasta grubu $(n=15)$, mean $\pm S D$ & Kontrol grubu $(n=7)$, mean \pm SD & P değeri \\
\hline Total testesteron & $5,89 \pm 1,55$ & $4,03 \pm 2,14$ & 0,030 \\
\hline DHEA-S & $171 \pm 96$ & $210 \pm 117$ & 0,423 \\
\hline \multirow{2}{*}{ Prolaktin } & $8,70 \pm 1,68$ & $8,29 \pm 5,14$ & 0,841 \\
\hline & Median (min-max) & Median (min-max) & \\
\hline TSH & $1,45(0,19-28,00)$ & $1,58(0,19-2,58)$ & 0,731 \\
\hline FSH/LH & $1,03(0,42-3,53)$ & $1,62(0,96-3,71)$ & 0,142 \\
\hline Estradiol & $36(28-48)$ & $41(35-52)$ & 0,039 \\
\hline
\end{tabular}

DHEA-S: Dehidroepiandrosteron sülfat. TSH: Tiroid stimüle edici hormon. FSH: Folikül stimüle edici hormon. LH: Lüteinize edici hormon. SD: Standart sapma. 
Depresyonun çölyak hastalığı ile ilişkisini ilk olarak Morris (15) ve Hallert (16) yaptıkları çalışmalarda tanımlamıştır. Birçok yazar tarafından da depresyonun çölyak hastalarında kontrol gruplarına göre daha sık görüldüğü rapor edilmiştir $(6,9)$. 36 çölyak hastası ve 144 kişilik kontrol grubu ile yapılan bir kesitsel vaka-kontrol çalışmasında çölyak hastalarında majör depresyon $(\% 41,7)$, distimik bozukluk $(\% 8,3)$, uyum bozukluğu $(\% 30,5)$ ve panik bozukluk $(\% 13,9)$ görülme risklerinde artış saptanırken, glutensiz diyet yapan çölyak hastalarında da depresyon ve anksiyete semptomlarında görülen artmış oranlar dikkat çekmektedir (6). Ludvigsson ve arkadaşlarının yapmış olduğu popülasyon bazlı kohort çalışmasında da çölyak hastalarında kontrol grubuna göre depresyon görülme riskinde \%80 artış tespit edilirken (9), sadece bir vaka-kontrol çalışmasında depresyon için benzer prevalans oranları bulunmuştur (\%17,2 ve \%16), (17).

Diğer çalışmaların aksine bizim çalışmamızda kontrol grubu ile çölyak hastaları arasında depresif semptomlar açısından anlamlı bir fark yoktu $(p>0,05)$. Hasta grubunda diğer çalışmalarla benzer oranlar mevcutken belki de kontrol grubumuzun yüksekliği istatistiksel olarak fark oluşturmamışır. Hasta ve kontrol grubu ayrı ayrı değerlendirildiğinde ise kadın ve erkekler arasında da depresyon semptomları açısından belirgin bir fark bulunamadı (srasıyla $p=0,83$ ve $p=0,26$ ). Her iki gruptaki katılımcı sayısının azlığı bunun bir nedeni olabiliceği gibi, hastaların en az 1 yıllık çölyak hastası olması ve bunun da hastalarda hastalığı kabullenme ve uyum sağlama için yeterli bir süre olması da bir başka neden olabilir.

Nachman ve arkadaşları çölyak hastalarında Beck depresyon envanterini kullanarak yapmış olduğu çalışmada, tedavisiz çölyak hastalarında depresyon prevalansının artmış olduğunu gösterirken bu hastaların glutensiz diyet sonrası 1. ve 4. yıllarda psikolojik semptomarında önemli ölçüde iyileşme gözlemlemişlerdir (18). Pynnönen ve arkadaşları da glutensiz diyete başladıktan sonra psikiyatrik semptomların çölyak hastalığı aktivitesinde azalmayla ilişkili olarak iyileştiğini göstermişlerdir (19). Bir başka çalışmada ise glutensiz diyet ile hastalarda anksiyete semptomlarının iyileştiği fakat depresif semptomların devam ettiği görülmüştür (20). Ciacci ve arkadaşları depresyon ile çölyak hastalığı süresi veya diyet uyumunun arasında bir ilişki bulamazken (7) Smith ve Gerdes'in metaanalizlerinin sonucunda da glutensiz diyetin yetişkin çölyak hastalarında depresif semptomları iyileştirmede yetersiz olduğu sonucuna varımıştır (21). Bu çalışmaların aksine Van Hees ve arkadaşları ise 2265 yetişkin çölyak hastasını içeren kesitsel çalışmalarında uzun süreli glutensiz diyete uyumun ( 5 yıldan fazla) yeni depresif semptom gelişme riskini azalttığını göstermiş olup (22) yine aynı çalışmada sıkı diyet ile depresif semptomlar arasında bir ilişki saptanmamıştır.

Katılımcıların hemoglobin düzeyleri ile Beck Depresyon Skorları arasında negatif korelasyon bulunması $(p=0,03)$ aneminin çölyak hastalığından bağımsız olarak depresyona yol açabileceğini göstermektedir. Korkmaz ve arkadaşlarının psikiyatrik bozukluğu olan hastalarda anemi sıkığı ile ilgili yapmış olduğu çalışmada depresyon tanısı olanların \%22'sinde görülen aneminin popülasyona oranla yüksek bulunması da bunu desteklemektedir (23). Aynı zamanda Van Millargen ve arkadaşları ise depresyon ve anksiyete tansı olan 2.920 katılımcı ile yaptığı çalışmada hem düşük hemoglobin düzeylerinin hem de yüksek hemoglobin düzeylerinin depresyon ve anksiyete ciddiyeti ile ilişkisini göstermiştir (24). Anemi kanın oksijenlenmesini azaltarak ve serebral hipoperfüzyona neden olarak hastalarda depresyona ve psikiyatrik problemlere yol açabilir. Bunun yanı sıra aneminin özellikle sosyoekonomik düzeyi düşük kişilerde beslenme bozukluğuna bağlı görülüyor olması da anemi ile birlikte depresyon sıklığının artmasına neden olabilir.

Seksüel disfonksiyon kronik hastalıklarda yoğun strese bağlı sık görülen bir semptom olarak karşımıza çıkmaktadır. Marin ve arkadaşlarının yaptığı vaka-kontrollü bir çalışmada 355 inflamatuvar barsak hastası ve 200 sağ|ıkı kontrol grubunun karşılaştırılması sonucu inflamatuvar barsak hastası ( $\mathrm{iBH}$ ) olan kadınların yarısında ve erkeklerin üçte birinde $\mathrm{I} B \mathrm{BH}$ tanısından sonra cinsel istek ve tatminkarlıkta azalma olduğu gösterilirken (25), Strippoli ve arkadaşlarının son dönem böbrek hastaları üzerinde yaptığı bir çalışmada ise 1.472 kadın hastadan 659'unun doldurduğu FSFI testine göre hastaların \%84'ünde (555) seksüel disfonksiyon saptanmıştır (26).

Atipik klinikle seyreden çölyak hastalığının ise hem erkek hem de kadınlarda infertilite problemleri ve gebelik komplikasyonları ile ortaya çıkabildiği bilinmektedir (27). Gonadal disfonksiyon çölyaklı erkek hastalarda gösterilmişken kadınlarda hormonal anormallik raporlanmamıştır $(14,28)$. Birçok kronik hastalık sürecinde ortaya çıkan seksüel disfonksiyonla ilgili çölyak hastalarında yapıımış çok az çalışma bulunmaktadır. Açıklanamayan infertilite ve hipogonadizm bazı çölyaklı erkeklerde gözlemlenmiş olup, glutenin diyetten çıkarılmasıyla sperm sayısı ve motilitesindeki artış ile daha önceden infertil olan kadınlarda başarılı gebelik görülmesi bunu desteklemiştir (29-31). Farthing ve arkadaşları 1982 'de yaptıkları çalışmada çölyaklı erkekler (subtotal villoz atrofisi olanlar ve normal jejunal biyopsisi olanlar) ile Crohn tanılı erkekleri hipogonadizm, seksüel disfonksiyon, sperm kalitesi ve fertilite açııından 
karşılaştırdıklarında subtotal villöz atrofisi olan çölyaklı erkeklerde seksüel aktivite sıklığında ve sabah ereksiyonunda belirgin azalma saptarken, libidoları benzer bulmuşlar. Yine aynı çalışmada çölyaklı erkeklerin \%19'unda erektil impotans tespit edilmişken Crohn tanılı erkeklerin hiçbirinde erektil impotans saptamamışlar (14).

Çalışmamızda cinsel aktif olan ve IIEF anketini doğru ve eksiksiz dolduran 15 çölyak tanılı erkek hasta değerlendirilmeye alındığında yaş ortalamaları $46,8 \pm 11,11$ olup hastaların 8 'inde $(\% 53,3)$ erektil impotans saptanırken kontrol grubunda ise 7 hastadan (yaş ortalaması $43,14 \pm 11,8$ ) sadece 2 'sinde $(\% 28,6)$ erektil impotans tespit edildi. Bu fark belirgin olmakla beraber istatiksel olarak anlamlı değildi $(p=0,381)$. Her iki hasta ve kontrol grubundaki cinsel aktif erkeklerin IIEF skorları birbirine benzerken Beck skorlarına bakıldığında hasta grubunda belirgin olarak yüksek bulunmasına karşın bu fark da istatiksel olarak anlamlı bulunamadı $(p>0,05)$. Cinsel aktif erkek katılımcı sayımızın azlığı bu sonucun en önemli sebebi olup daha çok katıımcı ile yapılacak olan çalışmalarda anlamlı bir fark saptanabilir.

Farthing ve aradaşlarının yapmış olduğu bir diğer çalışmada ise çölyaklı erkek hastaların hormonal düzeylerinin jejunal morfoloji, fertilite, sperm kalitesi ve seksüel fonksiyon ile ilişkisi araştııımış. Bu çalışmaya göre tedavi edilmeyen çölyaklı erkeklerde diğer kronik hastalığı olan hasta gruplarına (Crohn, Hodgkin, romatoid artrit) ve sağlıklı kontrol grubuna göre total testesteron ve LH düzeylerinde artış, DHEA-S düzeylerinde ise azalma saptanmış. Bu durumun tedavi edilmemiş çölyaklı hastalarda periferal 5- $\alpha$ redüktaz enzimindeki bozulmaya bağlı görülen androjen direnci ile ilişkili olabileceği sonucuna varımış (32). Bu hastalardan cinsel aktif olan 28 hastadan 5 'inde (\%18) erektil impotans tespit edilirken seksüel fonksiyonu normal olan hastalarla aralarında endokrinolojik olarak belirgin bir fark bulunmamış (32).

Çalışmamıza katılan cinsel aktif erkek hastalar hormonal açıdan değerlendirildiğinde hasta grubunda total testesteron düzeyi sağlıklı kontrol grubuna göre daha yüksek bulunurken $(p=0,030)$ estradiol düzeyi daha düşük saptandı $(p=0,039)$. DHEA-S düzeyleri hasta grubunda daha düşük, LH düzeyleri ise daha yüksek saptanmasına rağmen aradaki fark istatiksel olarak anlamlı değildi $(p>0,05)$. Bu durumun özellikle çölyak hastalarında görülen yüksek LH ve total testesteron düzeyleri ve düşük DHEA-S düzeyleri ile seyreden androjen direnci ile ilgili olduğu düşünüldü. Hasta grubunda total testesteron düzeyleri anlamlı olarak yüksek bulunurken LH düzeylerindeki yüksekliğin ve DHEA-S düzeylerindeki düşüklüğün istatiksel olarak an- lamlı olmaması yine çalışmamızın zayıf yönü olan katııımcı sayısının yetersizliği ile ilişkilidir.

Çölyaklı kadınlarda ise daha çok fertilite ile ilgili çalışmalar yapılmış olup özellikle açıklanamayan infertilitesi olan kadınlarda çölyak hastalığı sıkığındaki artış ve glutensiz diyet sonrası bu hastalarda gebelik oranlarındaki artış dikkat çekmiştir $(30,33)$.

Çalışmamızdaki hasta ve sağıklı gruptaki cinsel aktif kadınlar karşılaştıııldığında FSFI total ve alt grup skorları kontrol grubunda daha yüksek olmakla birlikte istatiksel olarak anlamlı değildi $(p>0,05)$. Çölyaklı kadın hastalar hormon düzeylerine göre karşılaştırıldığında cinsel disfonksiyonu olanlarda prolaktin düzeyi olmayanlara göre yüksek iken estradiol düzeyi cinsel disfonksiyonu olanlarda daha düşük bulundu ama bu farkın istatiksel olarak anlamı yoktu (sırasıyla $p=0,304, p=0,894$ ). DHEA-S, total testesteron, FSH, LH, TSH düzeyleri her iki hasta grubunda benzerdi $(p>0,05)$. Hasta grubunda cinsel disfonksiyon üzerine hastalık aktivitesi ve depresyonun etkisi bulunamadı. Kontrol grubu kendi içinde hormonal olarak değerlendirildiğinde cinsel disfonksiyonu olanlarda total testesteron düzeyi daha yüksek bulunmasına rağmen bu fark istatistiksel olarak anlamlı değildi $(p=0,215)$. DHEAS-S, estradiol, prolaktin, FSH/LH oranı, TSH düzeyleri her iki kontrol grubunda benzerdi $(p>0,05)$. Depresyonun cinsel disfonksiyon üzerine etkisine bakıldı̆ıında anlamlı bir fark bulunamadı. Hasta ve kontrol grubunda menopozda olan kadınların oranları ise birbirine benzerdi (sırasiyla \%20 ve \%16,7), ( $p>0,05)$.

Çalışmamızda hormonal bozukluğun seksüel disfonksiyona belirgin bir etkisi bulunamamıştır. Benzer olarak Garcia ve arkadaşlarının Colombia'lı kadınlarda yapmış olduğu prevalans çalışmasında hormonal değişikliklerin seksüel disfonksiyona etkisi bulunmamışken (34) Lombardi ve arkadaşlarının multiple sklerozlu ve spinal kord travmalı kadın hastalarda ayrı ayrı yapılan çalışmalarında da hormonal değişikliklerin seksüel disfonksiyona etkisi saptanamamıştır $(35,36)$. Atiş ve arkadaşlarının hipotiroidisi olan kadın hastalarda yaptığı çalışmada ise seksüel disfonksiyon oranlarının kontrol gruplarına göre anlamlı şekilde artmış olduğu gösterilirken (37) Ercan ve arkadaşlarının polikistik over sendromu olan hastalarda yaptığı çalışmada total testesteron ve serbest testesteron düzeyleri ile FSFI skoru arasında negatif korelasyon saptamışlardir (38).

Çalışmamızdaki kadınlarda görülen seksüel disfonksiyonun hormonal denge ya da hastalık aktivitesiyle bir bağlantısı bulunamamakla beraber hasta sayısının az olması çalışmamızın zayıf yönlerinden birisi olmuştur. Aynı zamanda hasta grubumuzdaki hastaların en az 1 yıllık 
çölyak hastası olmaları diyete uyum ve olası mekanizmaların düzelmesi için yeterli bir süre olup depresyon ve cinsel disfonksiyon oranlarının az olmasına neden olmuş olabilir.

Sonuç olarak; yapılan bu çalışmamızda hem depresif semptomlar açııından hem de seksüel disfonksiyon açısından çölyaklı hasta grubu ile sağlıklı kontrol grubu arasında istatiksel oarak belirgin bir fark bulunamamıştır. Katılımcıların hemoglobin düzeyleri ile Beck skorları arasındaki negatif korelasyon aneminin hastalıktan ba-

\section{KAYNAKLAR}

1. Gujral N, Freeman HJ, Thomson ABR. Celiac disease: Prevalence, diagnosis, pathogenesis and treatment. World J Gastroenterol 2012; 18(42): 6036-6059

2. Fasano A, ve ark Berti I, Gerarduzzi T, T değil, Colletti RB, Drago S, Elitsur Y, Yeşil PH, Guandalini S Hill kimliği. Prevalence of celiacdisease in at-risk and not-at-risk groups in the United States: a largemulticenterstudy. ArchInternMed. 2003; 163 :286-292.

3. Sood A, Midha V, Sood N, Kaushal V, Puri H. Increasing incidence of celiac disease in India. Am J Gastroenterol. 2001;96:2804-2805

5. Julio C. Bai, Michael Fried, Gino Roberto Corazza ve ark. World Gastroenterology Organisation Global Guidelines : celiac disease, April 2012

6. Addolorato G, Stefanini G F, Capristo E, Caputo F, Gasbarrini A, Gasbarrini G.Anxiety and depression in adult untreated celiac subjects and in patients affected by inflammatory bowel disease: a personality "trait" or a reactive illness? Hepatogastroenterology 1996,Nov-Dec;43(12):1513-7.

7. Carta MG, Hardoy MC, Boi MF, Mariotti S, Carpiniello B, Usai P. Association between panic disorder, major depressive disorder and celiac disease: a possible role of thyroid autoimmunity. J Psychosom Res 2002 Sep;53(3):789-93.

8. Ciacci C, lavarone A, Mazzacca G, De Rosa A. Depressive symptoms in adult coeliac disease. Scand J Gastroenterol 1998 Mar;33(3):24750.

9. Hernanz A, Polanco I. Plasma precursor amino acids of central nervous system monoamines in children with coeliac disease. Gut 1991 Dec;32(12):1478-81

13. Ludvigsson JF, Reutfors J, Osby U, Ekbom A, Montgomery SM. Celiac disease and risk of mood disorders - a general population based cohort study. J Affect Disord 2007; 99: 117-126.

14. Addolorato G, Di Giuda D, De Rossi G. et al. Regional cerebral hypoperfusion in patients with celiac disease. Am J Med 2004;/116:/312-7.

15. Kirby M, Danner E. Nutritional deficiencies in children on restricted diets. Pediatr Clin North Am 2009;56(5):1085-103.

16. Mariani P, Viti MG, Montuori M, La Vecchia A, Cipolletta E, Calvani $L$, et al. The gluten-free diet: a nutritional risk factor for adolescents with celiac disease?J Pediatr Gastroenterol Nutr 1998;27(5):51923.

17. Sher KS, Jayanthi V, Probert CS, Stewart CR, Mayberry JF; Infertility, obstetric and gynaecological problems in coeliac sprue.:DigDis. $1994 ; 12(3): 186$

18. Farthing M.J.G, Edwards C.R.W, Rees L.H et al.;male gonadal function in celiac disease: 1. sexual dyfunction, infertility and semen quality.: Gut, 1982, 23, 608-614

19. Smith $D$ and Gerdes L. Meta-analysis on anxiety and depression in adult celiac disease. Acta Psychiatr Scand 2012; 125: 183-193. ğımsız olarak depresif semptomlarla ilişkili olabileceğini gösteriyor. Çölyaklı erkek hastalarda saptanan testesteron düzeylerindeki artışın ise androjen direnci ile ilişkili olabileceği düşünülmektedir. Kadınlarla ilgili ise daha çok fertilite çalışmaları yapılmış olup bizim çalışmamızda kontrol grubu ve çölyaklı kadınlar benzer fertilitedeydiler. Çölyaklı kadın ve erkeklerdeki seksüel disfonksiyon ve hormonal bozukluğun ilişkisini belirleyebilmek için daha çok sayıda ve daha fazla katııımcılla yapılacak çalışmalara gerek duyulmaktadır.

20. Hallert C, Astrøm J and Sedvall G. Psychic disturbances in adult coeliac disease. Scand J Gastroenterol 1982; 17:25-28.

21. Garud S, Leffler D, Dennis M, Edwards-George J, Saryan D, Sheth S, et al. Interaction between psychiatric and autoimmune disorders in coeliac disease patients in the Northeastern United States. Aliment Pharmacol Ther 2009;29(8):898-905.

22. Nachman F, del Campo MP, Gonza' lez A, et al. Longterm deterioration of quality of life in adult patients with celiac disease is associated with treatment noncompliance.Dig Liver Dis 2010; 42: 685-691.

23. Pynnönen PA, IsometsäET, Verkasalo MA et al. Gluten-free diet may alleviate depressive and behavioral symptoms in adolescents with coeliac disease: a prospective follow-up case-series study. BMC Psychiatry. 2005; 5: 14

24. Addolorato G, Capristo E, Ghittoni G. et al. Anxiety but not depression decreases in coeliac patients after one-year gluten-free diet: a longitudinal study. Scand J Gastroenterol. 2001; 36: 502-506.

25. Smith DF, Gerdes LU. Meta-analysis on anxiety and depression in adult celiac disease. Acta Psychiatr Scand 2012; 125: 189-193

26. Van Hees N.J.M, Van der Does W, Giltay E.J. Coeliac disease, diet adherence and depressive symptoms. Journal of Psychosomatic Research 74 (2013) 155-160

27. Korkmaz S, Yıldız S, Korucu T ve ark. Frequency of anemia in chronic psychiatry patients. Neuropsychiatric Disease and Treatment 2015:11 2737-2741.

28. Lever-van Milligen BA, Vogelzangs N, Smit JH, Penninx BW. Hemoglobin levels in persons with depressive and/or anxiety disorders. J Psychosom Res. 2014;76:317-321

29. Marin L,Manosa M; Sexual Function and patient preceptions in inflammatory bowel disease:acase-controlsurvey: J.Gastroenterol 2013 jun;48(6):713-20.

30. Strippoli GF,VecchioM,PalmerS;Sexualdysfunction in womwnwith ESRD requiring hemodialysis:Clin J AmSoc Nephrol,2012 jun 7(6):974-81

31. Pablo Olivera, Juan Lasa. Celiac Disease and the Risk of Infertility. International Journal of Celiac Disease, 2015, Vol. 3, No. 3, 84-86

32. Jameson S. Zinc deficiency in malabsorption states: a cause of infertility? Acta Med Scan Suppl 1976;593:38-49.

33. Cooke WT, Peeney ALP, Hawkins CF. Symptoms, signs and diag nostic features of idiopathic steatorrhea. Q J Med 1953; 22: 59-77.

34. Morris JS, Adjukiewicz AB, Read AE. Coeliac infertility: an indication for dietary gluten restriction? Lancet 1970; 1: 213-4.

35. Baker PG, Read AB. Reversible infertility in male coeliac patients. $\mathrm{Br}$ Med J 1975; 2: 316-7

36. Farthing M.J.G, Edwards C.R.W, Rees L.H et al. Male gonadal function in coeliac disease: 2. Sex hormones. Gut, 1983; 24: 127-135. 
37. Collin P,Vilska S, Heinonen S.P ve ark. Infertility and coeliac disease. Gut 1996; 39: 382-384

38. Garcia S, Moreno S, Aponte H. Prevalence of Sexual Dysfunction in Female Outpatients and Personnel at a Colombian Hospital: Correlation with Hormonal Profile. J Sex Med 2008;5:1208-1213.

39. Lombardi G, Celso M, Bartelli M ve ark. Female Sexual Dysfunction and Hormonal Status in Multiple Sclerosis Patients. J Sex Med 2011;8:1138-1146.

40. Lombardi G, Mondaini N, Macchiarella A ve ark. Female sexual dysfunction and hormonal status in spinal cord injured (SCI) patients. J Androl. 2007 Sep-Oct;28(5):722-6.
41. Atis G, Dalkilinc A, Altuntas $Y$ ve ark. Sexual Dysfunction in Women with Clinical Hypothyroidism and Subclinical Hypothyroidism. J Sex Med 2010;7:2583-2590.

42. Ercan CM, Coksuer H,Aydogan $U$ ve ark. Sexual dysfunction assessment and hormonal correlations in patients with polycystic ovary syndrome. International Journal of Impotence Research (2013), 127-132. 